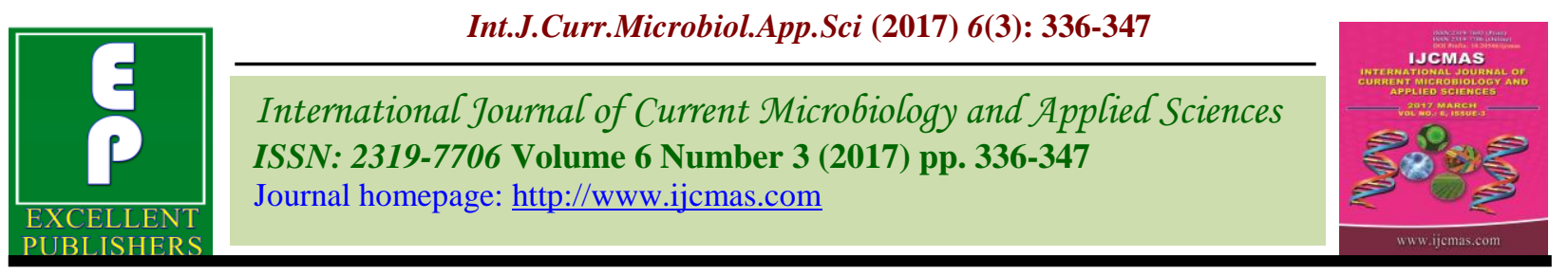

Original Research Article

https://doi.org/10.20546/ijcmas.2017.603.038

\title{
Impact of Edible Coatings on the Postharvest Behaviour of Bitter Gourd (Momordica charantia L.) Fruits
}

\author{
Donal Bhattacharjee* and Rabi Shankar Dhua
}

Department of Post Harvest Technology of Horticultural Crops, Faculty of Horticulture, Bidhan

Chandra Krishi Viswavidyalaya, Mohanpur- 741 252, Nadia, West Bengal, India

*Corresponding author

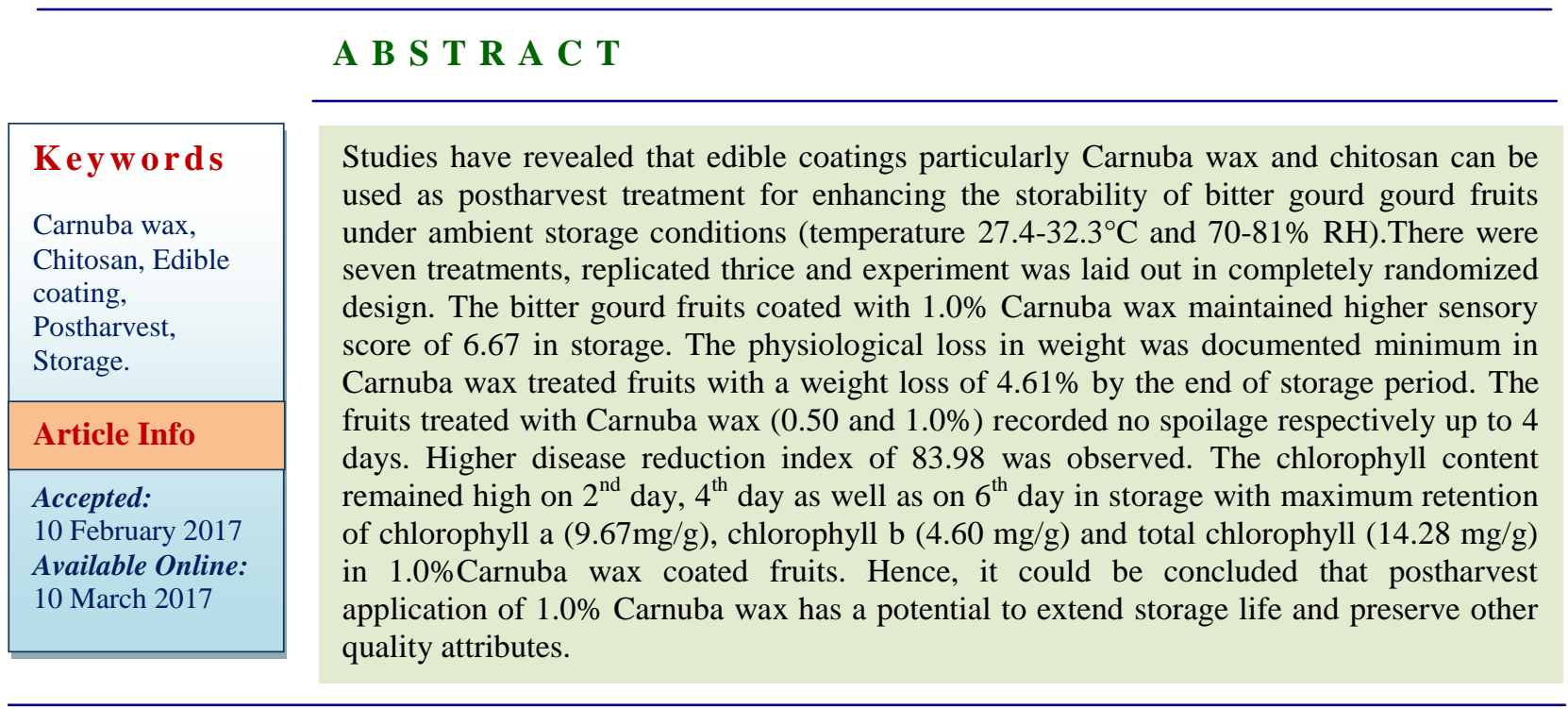

\section{Introduction}

Bitter gourd (Momordica charantia L., Family: Cucurbitaceae) is an important vegetable grown in the states of Uttar Pradesh, Bihar, West Bengal, Orissa, Assam, Maharashtra, Gujarat, Rajasthan, Punjab, Tamil Nadu, Kerala, Karnataka, and Andhra Pradesh. The fruits are used in traditional medications and in a wide variety of culinary preparations. The recent trends of improving dietary standards have placed this vegetable in consumers' platter due to its rich nutritional profile. So, the consumers demand for quality fruits which are judged by the colour, firmness and appearance. The major losses in the quality and quantity of fresh vegetables occur between harvest and consumption due to poor handling and marketing systems. The quality of bitter gourd can be maintained by development of technologies that can minimize deterioration and extend shelf life.

The use of edible coatings appears to be a promising approach in reducing postharvest deterioration and preserving the quality for storage. An edible film is a thin layer of material which can be eaten by the consumer, be applied on the vegetable by wrapping, dipping, brushing or spraying (Wu et al., 2002). It act as partial barriers to gases $\left(\mathrm{CO}_{2}\right.$ and $\mathrm{O}_{2}$ ) and moisture exchange, aroma 
compounds, decreasing the respiration rate of the fruit and water loss and preserving texture and flavour (Olivas and Barbosa-Canovas, 2005). In addition, edible coatings also carry certain functional ingredients such as antioxidants, antimicrobials, nutrients, and flavours to further enhance food stability, quality, functionality and safety (Debeaufort et al., 1998; Min and Krochta, 2005). The edible coatings can be classified into three categories based on the components used for preparation: hydrocolloids (such as proteins, polysaccharides, and alginate), lipids (such as fatty acids, acylglycerol, waxes) and composites (Donhowe and Fennema, 1993). Carnauba wax is an edible coating material under the lipid group, is a wax from the palm (Copernicia prunifera, Family: Arecaceae), a plant native to and grown only in the northeastern Brazilian states. It is obtained from the leaves of the carnauba palm by collecting and drying, beating them to loosen the wax, refining and bleaching the wax (Parish et al., 2002; Puttalingamma, 2014).The carnauba wax is well known for retaining postharvest properties of several fruits and vegetables during storage (Eum et al., 2009; Khuyen et al., 2008; Koley et al., 2009). Chitosan used as edible films or coatings are polysaccharides that come under the hydrocolloids group, is derived by deacetylation from chitin which is the second most abundant naturally occurring biopolymer after cellulose and is found in the exoskeleton of crustaceans, in fungal cell walls and other biological materials (No et al., 2007; Xu et al., 2005). Several studies have shown that chitosan is effective at extending the shelf life of fruits and vegetables (Jiang and $\mathrm{Li}, 2001$; Li and $\mathrm{Yu}, 2000$ ).

The experiment was planned with the hypothesis that coating of the bitter gourd fruits with two edible coatings viz. Carnuba wax and chitosan can preserve the quality attributes and extend the storability as well as the marketability. The present investigation was therefore has been undertaken with the objective to study the relative effectiveness of Carnuba wax and chitosan as edible coatings on the storage behaviour of bitter gourd.

\section{Materials and Methods}

The experiment was carried out in the laboratory conditions of the Department of Post Harvest Technology of Horticultural Crops, Bidhan Chandra Krishi Viswavidyalaya, WestBengal, India. Fresh fruits of bitter gourd cv. Meghna-2 were used for the present experiment. Fruits of uniform colour, size and maturity, without injuries were sorted out and washed. The fruits were washed with chlorine (100 ppm) water for 10 minutes using sodium hypochlorite (4.4\% $\mathrm{w} / \mathrm{w}$, as a source of chlorine). Then they were surface dried by keeping under fan in an airy place. The fruits were dipped in Carnuba wax and chitosan solutions respectively for 10 minutes. All the treatments were kept on trays and stored in normal room condition. The temperature and relative humidity of the atmosphere during the study period ranged from $27.4-32.3^{\circ} \mathrm{C}$ and $70-81 \%$ respectively. There were seven treatments viz., $\mathrm{T}_{1}$ - Control, $\mathrm{T}_{2}$-Carnuba wax $0.25 \%, \mathrm{~T}_{3}$-Carnuba wax $0.50 \%, \mathrm{~T}_{4}$-Carnuba wax $1.0 \%, \mathrm{~T}_{5}$-Chitosan $0.25 \%, \mathrm{~T}_{6}$-Chitosan $0.50 \%$ and $\mathrm{T}_{7}$-Chitosan $1.0 \%$. The Carnuba wax was prepared in the laboratory by solubilizing it in trimethyl amine and oleic acid with the help of boiled water at a temperature of about $100^{\circ} \mathrm{C}$. For Chitosan coating, the solution was prepared by dissolving $1 \%$ Chitosan (Sigma Chemical Co.) in a $0.5 \%$ glacial acetic acid and distilled water. The $\mathrm{pH}$ value of the Chitosan solution was then adjusted to 5.6 using $0.1 \mathrm{M} \mathrm{NaOH}$ (Bal, 2013).From the stock solution three different concentration of coating $(0.25,0.50$ and $1.0 \%$ ) were prepared. The analysis of data obtained in experiments was analyzed by Completely Randomized Design with three 
replications, by adopting the statistical procedures of Gomez and Gomez (1984). The means between treatments were compared by Duncan's multiple range tests (DMRT) (Duncan, 1955).

\section{Sensory evaluation}

During the period of study, observations on sensory properties were estimated byusing9point Hedonic scale for their sensory characteristics like appearance, texture and overall acceptability. The scores were assigned from extremely liked (9) to disliked extremely (1) (Kaur and Aggarwal, 2015).

\section{Physiological loss in weight (PLW)}

The weight of individual fruit in the experiment was taken on the day of observation and the percentage of loss in weight on the day of observation was calculated on the basis of the initial weight and expressed in percentage.

\section{$\operatorname{PLW}(\%)=$}

$\frac{\text { Initial fruit weight-Weight of fruit on observation day }}{\text { Initial fruit weight }} \times 100$

\section{Spoilage}

Spoilage percentage was observed after every 48 hours and was calculated as described below (Bhat et al., 2014).

Spoilage $(\%)=$

$\frac{\text { Number of decayed fruita at the time of ampling }}{\text { Initial number of fruits }} \times 100$

\section{Disease reduction index (DRI)}

The disease reduction index was estimated from the numbered fruits of each experimental lot at each date of observation and disease reduction index was calculated by the following formula (Gutter, 1969).

$\mathrm{DRI}=$

$\frac{\text { Percent disease in control-Percent disease in treatment }}{\text { Percent disease in control }} \times 100$

\section{Chlorophyll content}

Chlorophyll a, b and total chlorophyll was extracted in $80 \%$ acetone and absorption was measured at $663 \mathrm{~nm}$ and $645 \mathrm{~nm}$ by spectrophotometer (Systronics Spectrophotometer 166) and expressed as mg chlorophyll per gram of fresh tissueat regular time interval. Using the absorption coefficients, the amount of chlorophyll is calculated using the following equations (Sadasivam and Manickam, 1996):

mg chlorophyll a/ $\mathrm{g}$ tissue $=$

$12.7\left(\mathrm{~A}_{663}\right)-2.69\left(\mathrm{~A}_{645}\right) \times \frac{\mathrm{v}}{1000 \mathrm{xW}}$

mg chlorophyll $\mathrm{b} / \mathrm{g}$ tissue $=$

$22.9\left(\mathrm{~A}_{645}\right)-4.68\left(\mathrm{~A}_{663}\right) \mathrm{x} \frac{\mathrm{v}}{1000 \mathrm{xW}}$

and $\mathrm{mg}$ total chlorophyll $/ \mathrm{g}$ tissue $=$

$$
20.2\left(\mathrm{~A}_{645}\right)+8.02\left(\mathrm{~A}_{663}\right) \times \frac{\mathrm{v}}{1000 \mathrm{xW}}
$$

where, $\mathrm{A}=$ absorbance at specific wavelengths

$\mathrm{V}=$ final volume of chlorophyll extract in $80 \%$ acetone

$\mathrm{W}=$ fresh weight of tissue extracted.

\section{Results and Discussion}

The sensory properties evaluated on the basis of sensory score are shown in table 1 . Up to $4^{\text {th }}$ day of storage, the sensory quality of $\mathrm{T}_{4}$ (Carnuba wax 1.0\%) was very good to good as indicated by sensory score of 8.67 and 8.00 respectively. On $6^{\text {th }}$ day, more or less the 
treatments were fair to non-acceptable. The score of $\mathrm{T}_{4}$ (6.67) was significantly superior to other treatments. This may be attributed to the micro emulsions of Carnauba wax that controls water loss and add shine (Baldwin, 1994). The wax coating retard colour change and delay biochemical changes and extend ripening and senescence of fruit. It plugs the openings of the fruit skin surface thereby reduce their metabolic activities by lowering the rates of respiration and transpiration,this successfully prolonging their shelf life (Amarante and Banks, 2001). Similar results were observed by Barman et al., (2011).

The physiological loss of weight of bitter gourd fruits under different treatments at three days interval in storage has been presented in table 2. Physiological loss of weight differed significantly among the treatments throughout the period of storage. The weight loss increased gradually in all the treatments with advancement of storage period. By the end of storage period similar trend of physiological loss of weight prevailed and it varied from $4.61 \%$ in $\mathrm{T}_{4}$ (Carnuba wax $1.0 \%$ ) to $26.49 \%$ in control. However, per cent increase in weight loss was recorded significantly low in $1.0 \%$ Carnuba wax treated fruits followed by $0.50 \%$ Carnuba wax and highest in control. Thus, it was observed that the physiological loss of weight in Carnuba wax treated bitter gourd fruits remained lower than the chitosan coated fruits. The weight loss in fresh vegetables is mainly due to the loss of water caused by transpiration and respiration processes. Coating the bitter gourd fruits with $1.0 \%$ Carnuba wax is evidently effective in conferring a physical barrier to moisture loss and therefore retarding dehydration and fruit shriveling (Hu et al., 2011). The reduction in weight loss is may be due to the coating that manipulates levels of oxygen and carbon dioxide within fruits and creates a modified atmosphere that reduces the water vapour transmission and therefore respiration rates.
The results are in close conformity with that of Arumugam and Balamohan (2014).

The influence of edible coating materials on spoilage of bitter gourd fruits were illustrated in table 3. The spoilage of bitter gourd fruits were minimum with Carnuba wax treatment followed by chitosan from second to sixth days of storage. With the advancement of storage period, the effectiveness of coating materials declined. On $2^{\text {nd }}$ day of storage, no spoilage was recorded in any of the treatments. The highest spoilage was observed in control $(27.18 \%)$ whereas, no spoilage was noted in $\mathrm{T}_{3}$ (Carnuba wax $0.50 \%$ ) and $\mathrm{T}_{4}$ (Carnuba wax 1.0\%) respectively on $4^{\text {th }}$ day of storage. On $6^{\text {th }}$ day, the minimum spoilage of $27.61 \%$ was reported in $\mathrm{T}_{4}$ (Carnuba wax 1.0\%) followed by $\mathrm{T}_{2}$ (Carnuba wax $0.25 \%$ ) $(29.23 \%$ ) with maximum spoilage of $98.83 \%$ in control. This was due to the reason that coating with Carnuba wax sealed the opening on the surface of the fruit there by preventing incidence of moulds (Torres et al., 2009). Waxing creates a barrier to resist the pathogens of fungi and bacteria to penetrate into the product. Similar results were observed by Singhand Singh (2002).

The data on disease reduction index (DRI) of bitter gourd fruits were presented in table 4, which revealed that the disease incidence started from $4^{\text {th }}$ day onwards in storage. The DRI recorded in all treated fruits were significantly higher as compared to control till the end of storage. $\mathrm{T}_{3}$ (Carnuba wax $0.50 \%$ ) and $\mathrm{T}_{4}$ (Carnuba wax $1.0 \%$ ) recorded highest DRI on $4^{\text {th }}$ day of storage. However, on $6^{\text {th }}$ day, highest DRI was recorded in $\mathrm{T}_{4}$ (Carnuba wax $1.0 \%$ ) (83.98) followed by lowest being $0.89\left(\mathrm{~T}_{6^{-}}\right.$Chitosan $\left.0.50 \%\right)$ and $0.00\left(\mathrm{~T}_{7^{-}}\right.$ Chitosan $1.0 \%$ and $\mathrm{T}_{1}$ - Control) respectively. 
Int.J.Curr.Microbiol.App.Sci (2017) 6(3): 336-347

Table.1 Effect of edible coatings on sensory properties of bitter gourd fruits in storage

\begin{tabular}{|c|c|c|c|}
\hline \multirow{3}{*}{ Treatments } & \multicolumn{3}{|c|}{ Sensory properties } \\
\hline & \multicolumn{3}{|c|}{ Days in storage } \\
\hline & 2 & 4 & 6 \\
\hline $\mathbf{T}_{1}$ & $3.00 \mathbf{a}$ & $1.67 \mathbf{a}$ & $1.33 \mathrm{a}$ \\
\hline $\mathbf{T}_{2}$ & $7.33 \mathbf{c d}$ & $5.67 d$ & $4.67 \mathrm{c}$ \\
\hline $\mathbf{T}_{3}$ & $8.00 \mathrm{de}$ & $6.67 \mathbf{d}$ & $6.00 \mathrm{~d}$ \\
\hline $\mathbf{T}_{4}$ & $8.67 e$ & $8.00 \mathrm{e}$ & $6.67 \mathbf{d}$ \\
\hline $\mathbf{T}_{\mathbf{5}}$ & $6.67 \mathrm{c}$ & $4.00 \mathbf{c}$ & $3.33 \mathbf{b}$ \\
\hline $\mathbf{T}_{6}$ & $5.33 \mathbf{b}$ & $3.67 \mathrm{bc}$ & $3.00 \mathrm{~b}$ \\
\hline $\mathbf{T}_{7}$ & $4.33 \mathbf{b}$ & $2.67 \mathbf{a b}$ & $1.67 \mathbf{a}$ \\
\hline C.D. (0.05) & 1.280 & 1.280 & 1.280 \\
\hline $\operatorname{SEm} \pm$ & 0.418 & 0.418 & 0.418 \\
\hline
\end{tabular}

(Means in the column followed by the same alphabet do not differ significantly by DMRT at 5\%)

$\left(\mathrm{T}_{1^{-}}\right.$Control, $\mathrm{T}_{2^{-}}$Carnuba wax $0.25 \%, \mathrm{~T}_{3^{-}}$Carnuba wax $0.50 \%, \mathrm{~T}_{4^{-}}$Carnuba wax $1.0 \%, \mathrm{~T}_{5^{-}}$Chitosan $0.25 \%, \mathrm{~T}_{6}-\mathrm{Chitosan} 0.50 \%, \mathrm{~T}_{7^{-}}$Chitosan $1.0 \%$ ) 
Table.2 Changes in the physiological loss in weight of bitter gourd fruits in storage as affected by the edible coatings

\begin{tabular}{|c|c|c|c|}
\hline \multirow{3}{*}{ Treatments } & \multicolumn{3}{|c|}{ Physiological loss in weight $(\%)$} \\
\hline & \multicolumn{3}{|c|}{ Days in storage } \\
\hline & 2 & 4 & 6 \\
\hline $\mathbf{T}_{1}$ & $\begin{array}{l}8.34 \mathbf{d} \\
(3.05)\end{array}$ & $\begin{array}{c}19.43 \mathbf{e} \\
(4.52)\end{array}$ & $26.49 \mathbf{e}$ \\
\hline $\mathbf{T}_{\mathbf{2}}$ & $\begin{array}{c}5.29 b c \\
(2.50)\end{array}$ & $\begin{array}{c}7.47 \mathbf{c} \\
(2.91)\end{array}$ & $\begin{array}{c}13.72 \mathbf{d} \\
(3.84)\end{array}$ \\
\hline $\mathbf{T}_{\mathbf{3}}$ & $\begin{array}{c}4.82 \mathbf{b} \\
(2.41)\end{array}$ & $\begin{array}{c}6.12 \mathbf{b c} \\
(2.66)\end{array}$ & $\begin{array}{c}6.63 \mathbf{b} \\
(2.76)\end{array}$ \\
\hline $\mathbf{T}_{4}$ & $\begin{array}{c}2.40 \mathbf{a} \\
(1.84)\end{array}$ & $\begin{array}{l}3.43 \mathbf{a} \\
(2.10)\end{array}$ & $\begin{array}{l}4.61 \mathbf{a} \\
(2.37)\end{array}$ \\
\hline $\mathbf{T}_{\mathbf{5}}$ & $\begin{array}{c}5.31 \mathbf{b c} \\
(2.51)\end{array}$ & $\begin{array}{c}5.61 \mathbf{b} \\
(2.57)\end{array}$ & $\begin{array}{r}8.31 \mathrm{c} \\
(3.05)\end{array}$ \\
\hline $\mathbf{T}_{6}$ & $\begin{array}{c}6.23 \mathbf{b c} \\
(2.69)\end{array}$ & $\begin{array}{c}7.10 \mathbf{b c} \\
(2.84)\end{array}$ & $\begin{array}{c}13.23 d \\
(3.77)\end{array}$ \\
\hline $\mathbf{T}_{7}$ & $\begin{array}{c}6.52 \mathbf{c} \\
(2.74) \\
\end{array}$ & $\begin{array}{c}10.36 \mathbf{d} \\
(3.37) \\
\end{array}$ & $\begin{array}{r}13.38 d \\
(3.79) \\
\end{array}$ \\
\hline C.D. (0.05) & 0.272 & 0.268 & 0.200 \\
\hline $\mathrm{SEm} \pm$ & 0.089 & 0.087 & 0.065 \\
\hline
\end{tabular}

* figures in parenthesis indicates angular transformed values

(Means in the column followed by the same alphabet do not differ significantly by DMRT at 5\%)

( $\mathrm{T}_{1^{-}}$Control, $\mathrm{T}_{2^{-}}$Carnuba wax $0.25 \%, \mathrm{~T}_{3^{-}}$Carnuba wax $0.50 \%, \mathrm{~T}_{4^{-}}$Carnuba wax $1.0 \%, \mathrm{~T}_{5^{-}}$Chitosan $0.25 \%, \mathrm{~T}_{6^{-}}$Chitosan $0.50 \%, \mathrm{~T}_{7^{-}}$Chitosan $1.0 \%$ ) 
Int.J.Curr.Microbiol.App.Sci (2017) 6(3): 336-347

Table.3 Influence of edible coating materials on spoilage of bitter gourd fruits

\begin{tabular}{|c|c|c|c|}
\hline \multirow{3}{*}{ Treatments } & \multicolumn{3}{|c|}{ Spoilage (\%) } \\
\hline & \multicolumn{3}{|c|}{ Days in storage } \\
\hline & 2 & 4 & 6 \\
\hline $\mathbf{T}_{\mathbf{1}}$ & $\begin{array}{c}0.00 \mathbf{a} \\
(0.81)\end{array}$ & $\begin{array}{l}27.18 \mathrm{~d} \\
(31.40)\end{array}$ & $\begin{array}{c}98.83 \mathbf{e} \\
(86.40)\end{array}$ \\
\hline $\mathbf{T}_{2}$ & $\begin{array}{c}0.00 \mathbf{a} \\
(0.81)\end{array}$ & $\begin{array}{c}5.73 \mathbf{b} \\
(13.78)\end{array}$ & $\begin{array}{c}29.23 \mathbf{a b} \\
(32.71)\end{array}$ \\
\hline $\mathbf{T}_{3}$ & $\begin{array}{c}0.00 \mathbf{a} \\
(0.81)\end{array}$ & $\begin{array}{c}0.00 \mathbf{a} \\
(0.81)\end{array}$ & $\begin{array}{c}30.22 \mathbf{b} \\
(33.33)\end{array}$ \\
\hline $\mathbf{T}_{4}$ & $\begin{array}{c}0.00 \mathbf{a} \\
(0.81)\end{array}$ & $\begin{array}{c}0.00 \mathbf{a} \\
(0.81)\end{array}$ & $\begin{array}{r}27.61 \mathbf{a} \\
(31.69)\end{array}$ \\
\hline $\mathbf{T}_{5}$ & $\begin{array}{c}0.00 \mathbf{a} \\
(0.81)\end{array}$ & $\begin{array}{c}5.92 \mathbf{b} \\
(14.08)\end{array}$ & $\begin{array}{c}69.36 \mathbf{c} \\
(56.37)\end{array}$ \\
\hline $\mathbf{T}_{6}$ & $\begin{array}{c}0.00 \mathbf{a} \\
(0.81)\end{array}$ & $\begin{array}{c}6.97 \mathbf{b} \\
(15.30)\end{array}$ & $\begin{array}{c}70.04 \mathbf{c d} \\
(56.79)\end{array}$ \\
\hline $\mathbf{T}_{7}$ & $\begin{array}{r}0.00 \mathbf{a} \\
(0.81) \\
\end{array}$ & $\begin{array}{c}10.07 \mathbf{c} \\
(18.50) \\
\end{array}$ & $\begin{array}{r}71.58 \mathbf{d} \\
(57.77) \\
\end{array}$ \\
\hline C.D. (0.05) & - & 1.282 & 4.258 \\
\hline $\mathrm{SEm} \pm$ & - & 0.419 & 1.390 \\
\hline
\end{tabular}

* figures in parenthesis indicates angular transformed values

(Means in the column followed by the same alphabet do not differ significantly by DMRT at 5\%)

$\left(\mathrm{T}_{1^{-}}\right.$Control, $\mathrm{T}_{2^{-}}$Carnuba wax $0.25 \%, \mathrm{~T}_{3^{-}}$Carnuba wax $0.50 \%, \mathrm{~T}_{4^{-}}$Carnuba wax $1.0 \%, \mathrm{~T}_{5^{-}}$Chitosan $0.25 \%, \mathrm{~T}_{6}-\mathrm{Chitosan} 0.50 \%, \mathrm{~T}_{7^{-}}$Chitosan $1.0 \%$ ) 
Int.J.Curr.Microbiol.App.Sci (2017) 6(3): 336-347

Table.4 Disease reduction index at different days in storage of bitter gourd fruits

\begin{tabular}{|c|c|c|c|}
\hline \multirow{3}{*}{ Treatments } & \multicolumn{3}{|c|}{ Disease reduction index } \\
\hline & \multicolumn{3}{|c|}{ Days in storage } \\
\hline & 2 & 4 & 6 \\
\hline $\mathbf{T}_{1}$ & 100.00 & 0.00 & 0.00 \\
\hline $\mathbf{T}_{2}$ & 100.00 & 77.83 & 76.39 \\
\hline $\mathbf{T}_{\mathbf{3}}$ & 100.00 & 100.00 & 82.13 \\
\hline $\mathbf{T}_{4}$ & 100.00 & 100.00 & 83.98 \\
\hline $\mathbf{T}_{\mathbf{5}}$ & 100.00 & 39.24 & 4.22 \\
\hline $\mathbf{T}_{6}$ & 100.00 & 28.40 & 0.89 \\
\hline $\mathbf{T}_{7}$ & 100.00 & 22.42 & 0.00 \\
\hline
\end{tabular}

$\left(\mathrm{T}_{1^{-}}\right.$Control, $\mathrm{T}_{2^{-}}$Carnuba wax $0.25 \%, \mathrm{~T}_{3^{-}}$Carnuba wax $0.50 \%, \mathrm{~T}_{4^{-}}$Carnuba wax $1.0 \%, \mathrm{~T}_{5^{-}}$Chitosan $0.25 \%, \mathrm{~T}_{6^{-}}$Chitosan $0.50 \%, \mathrm{~T}_{7^{-}}$Chitosan $\left.1.0 \%\right)$ 
Table.5 Chlorophyll a, chlorophyll b and total chlorophyll content at different days of storage of bitter gourd

\begin{tabular}{|c|c|c|c|c|c|c|c|c|c|}
\hline \multirow[b]{4}{*}{ 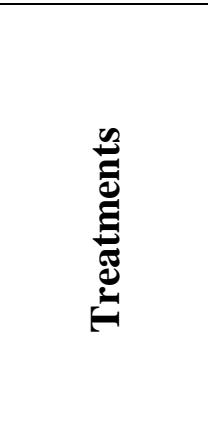 } & \multicolumn{9}{|c|}{ Pigment concentration $(\mathrm{mg} / \mathrm{g})$} \\
\hline & \multicolumn{9}{|c|}{ Days in storage } \\
\hline & \multicolumn{3}{|c|}{2} & \multicolumn{3}{|c|}{4} & \multicolumn{3}{|c|}{6} \\
\hline & $\begin{array}{c}\frac{\pi}{\bar{z}} \\
\frac{1}{2} \\
\frac{0}{0} \\
\frac{0}{2}\end{array}$ & 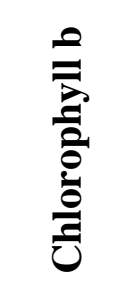 & 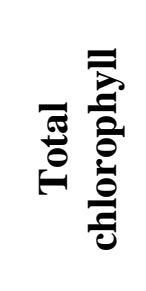 & 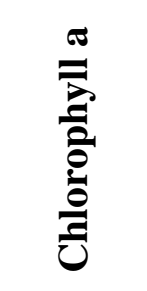 & 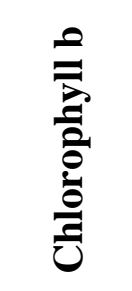 & 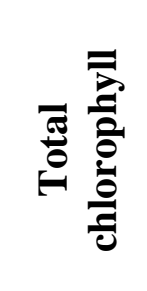 & 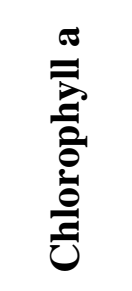 & 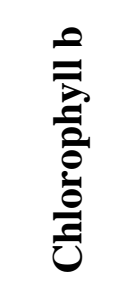 & 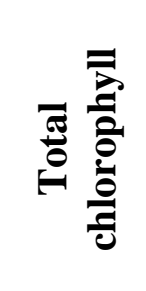 \\
\hline $\mathbf{T}_{1}$ & $7.64 \mathbf{a}$ & $3.07 \mathbf{a}$ & $11.28 \mathbf{a}$ & $5.55 \mathbf{a}$ & $2.64 \mathbf{a}$ & $8.19 \mathbf{a}$ & $3.45 \mathbf{a}$ & $1.64 \mathbf{a}$ & $5.10 \mathbf{a}$ \\
\hline $\mathbf{T}_{2}$ & $10.36 \mathbf{e}$ & $4.93 \mathbf{e}$ & $15.30 \mathbf{e}$ & $8.99 \mathbf{e}$ & $4.28 \mathbf{e}$ & $13.27 \mathbf{e}$ & $7.63 \mathbf{e}$ & $3.63 \mathrm{e}$ & $11.26 \mathbf{e}$ \\
\hline $\mathbf{T}_{3}$ & $10.49 \mathbf{e}$ & $5.00 \mathrm{e}$ & $15.49 \mathrm{e}$ & $9.67 \mathbf{f}$ & $4.61 \mathbf{f}$ & $14.28 \mathbf{f}$ & $8.31 \mathbf{f}$ & $3.96 \mathbf{f}$ & $12.27 \mathbf{f}$ \\
\hline $\mathbf{T}_{4}$ & $11.05 \mathbf{f}$ & $5.26 \mathbf{f}$ & $16.31 \mathbf{f}$ & $10.36 \mathbf{g}$ & $4.93 \mathbf{g}$ & $15.29 \mathrm{~g}$ & $9.67 \mathbf{g}$ & $4.60 \mathrm{~g}$ & $14.28 \mathbf{g}$ \\
\hline $\mathbf{T}_{5}$ & $9.68 \mathrm{~d}$ & $4.61 \mathrm{~d}$ & $14.29 \mathrm{~d}$ & $8.31 \mathbf{d}$ & $3.96 \mathrm{~d}$ & $12.27 \mathbf{d}$ & $6.94 \mathrm{~d}$ & $3.30 \mathrm{~d}$ & $10.25 \mathbf{d}$ \\
\hline $\mathbf{T}_{6}$ & $9.00 \mathbf{c}$ & $4.29 \mathrm{c}$ & $13.29 \mathrm{c}$ & $7.63 \mathbf{c}$ & $3.63 \mathrm{c}$ & $11.26 \mathrm{c}$ & $6.25 \mathrm{c}$ & $2.98 \mathrm{c}$ & $9.23 \mathrm{c}$ \\
\hline $\mathbf{T}_{7}$ & $8.32 \mathbf{b}$ & $3.96 \mathbf{b}$ & $12.28 \mathbf{b}$ & $6.93 \mathbf{b}$ & $3.30 \mathbf{b}$ & $10.24 \mathbf{b}$ & $5.55 \mathrm{~b}$ & $2.64 \mathbf{b}$ & $8.20 \mathrm{~b}$ \\
\hline C.D. (0.05) & 0.488 & 0.186 & 0.283 & 0.270 & 0.151 & 0.204 & 0.283 & 0.301 & 0.097 \\
\hline SEm \pm & 0.159 & 0.061 & 0.092 & 0.088 & 0.049 & 0.067 & 0.092 & 0.098 & 0.032 \\
\hline
\end{tabular}

$\left(\mathrm{T}_{1}\right.$ - Control, $\mathrm{T}_{2}$ - Carnuba wax $0.25 \%, \mathrm{~T}_{3^{-}}$Carnuba wax $0.50 \%, \mathrm{~T}_{4}$ - Carnuba wax $1.0 \%, \mathrm{~T}_{5^{-}}$Chitosan $0.25 \%, \mathrm{~T}_{6^{-}}$Chitosan $0.50 \%, \mathrm{~T}_{7}-$ Chitosan $\left.1.0 \%\right)$

(Means in the column followed by the same alphabet do not differ significantly by DMRT at $5 \%$ ) 
The bitter gourd fruits coated with Carnuba wax $(1.0 \%)$ upheld fairly high DRI compared to uncoated fruits throughout the storage period. Coatings on vegetables act as lubricants to reduce surface injury, scarring, and chafing. With less wounding of the fruit, decay due to opportunistic wound pathogens is lessened which in turn maintained higher DRI values. This has also been reported for carnauba wax by Baldwin et al., (1997).

The change in colour of bitter gourd fruits from green to yellow continued over the storage period (Table 5). The initial chlorophyll a, chlorophyll b and total chlorophyll content of bitter gourd fruits were $11.72 \mathrm{mg} / \mathrm{g}, \quad 5.59 \mathrm{mg} / \mathrm{g}$ and $17.31 \mathrm{mg} / \mathrm{g}$ respectively. This reference value decreased significantly with the storage time. By the end of storage time, highest retention of chlorophyll a $(9.67 \mathrm{mg} / \mathrm{g})$, chlorophyll b (4.60 $\mathrm{mg} / \mathrm{g})$ and total chlorophyll $(14.28 \mathrm{mg} / \mathrm{g})$ was recorded in $\mathrm{T}_{4}$ (Carnuba wax 1.0\%) and lowest chlorophyll a $(3.45 \mathrm{mg} / \mathrm{g})$, chlorophyll b (1.64 mg/g) and total chlorophyll (5.10 $\mathrm{mg} / \mathrm{g}$ ) in control. The chlorophyll content of the bitter gourd fruit was affected by treatments and varied significantly in storage periods. Overall, chlorophyll content decreased over the course of storage, and this decrease was strongly influenced by storage duration. Coated fruits had a significantly higher amount of chlorophyll than that of uncoated fruits, especially loss of surface green color might be associated with the natural ripening process triggered by ethylene, which occurs as the result of chlorophyll molecule breakdown and parallel to an increase in carotenoids content (Yamauchi, 2008). Therefore, application of wax delayed natural metabolic process that culminates with peel yellowing. The green color retention by application of coatings was reported by Shahid and Abbasi (2011) and Koley et al., (2009).
The present study showed that coatings were effective in delaying ripening, reducing the weight loss, decay incidences, maintaining pigment concentration and enhanced the shelf-life of bitter gourd fruits during storage. It could be concluded that coating the fruits with Carnuba wax was more promising than that of chitosan. Thus, Carnuba wax could be a good alternative for preserving the quality and extending the storage of fresh bitter gourd fruits.

\section{Acknowledgement}

The first author acknowledges INSPIRE Fellowship Programme of the Department of Science and Technology under Ministry of Science and Technology, New Delhi for the financial assistance for conducting the present investigation.

\section{References}

Amarante, C.V.T., and Banks, N.H. 2001. Postharvest physiology and quality of coated fruits and vegetables. Hort. Rev., 26: 161-238.

Arumugam, V., and Balamohan, T.N. 2014.Wax coating affects postharvest shelf-life of non-cooled sweet pepper. $J$. Spices Aromatic Crops, 23: 98-101.

Bal, E. 2013. Postharvest application of chitosan and low temperature storage affect respiration rate and quality of plum fruits. J. Agr. Sci. Tech., 15: 12191230.

Baldwin, E.A. 1994. Edible coatings for fresh fruits and vegetables: past, present and future. In: Krochta, J., Baldwin, E.A., Nisperos, M.O., (Eds.) Edible coatings and films to improve food quality. Technomic Publishing CO., INC., Lancaster, PA, USA, 1-65 and 25-64.

Baldwin, E.A., Nisperos-Carriedo, M.O., Hagenmaier, R.D., and Baker, R.A. 1997. Use of lipids in edible coatings 
for food products. Food Technol., 51: 56-62.

Barman, K., Asrey, R., and Pal, R.K. 2011. Putrescine and carnauba wax pretreatments alleviate chilling injury, enhance shelf life and preserve pomegranate fruit quality during cold storage. Sci. Hortic., 130: 795-800.

Bhat, A., Kaul, R.K., Reshi, M., and Gupta, N. 2014.Effect of polyamines on shelf life and chilling injury of mango cv. Dashehari. The Bioscan, 9(3): 10971100.

Debeaufort, F., Quezada-Gallo, J.A., and Voilley, A. 1998. Edible films and coatings: tomorrow's packagings: A review. Crit. Rev. Food Sci. Nutr., 38: 299-313.

Donhowe, I.G., and Fennema, O.R. 1993. The effects of plasticizers on crystallinity, permeability, and mechanical properties of methylcellulose films. J. Food Process. Preserv., 17: 247-257.

Duncan, D.B. 1955. Multiple range and Multiple F. Tests. Biometrics, 11: 1-42.

Eum, H.L., Hwang, D.K., Linke, M., Lee, S.K., and Zude, M. 2009. Influence of edible coating on quality of plum (PrunussalicinaLindl. cv. 'Sapphire'). Eur. Food Res. Technol., 229: 427-434.

Gomez, K.A., and Gomez, A.A. 1984.Statistical Procedures for Agricultural Research (2 ${ }^{\text {nd }}$ Ed.).WileyInter Science Publication (John Wiley and Sons) New York, USA.

Gutter, Y. 1969.Comparative effectiveness of benomyl, thiabendazole and other antifungal compounds for post harvest control of Penicillium decay in Sharmouti and Valencia oranges. Plant Dis. Reptr., 53: 474-478.

Hu, H., Li, X., Dong, C., and Chen, W. 2011. Effects of wax treatment on quality and postharvest physiological of pineapple fruit in cold storage. Afr. J. Biotechnol., 10: 7592-7603.
Jiang, Y., and Li, Y.2001.Effect of chitosan coating on postharvest life and quality of longan fruit. Food Chem., 73: 139143.

Kaur, S., and Aggarwal, P. 2015.Effect of addition of dehydrated potato flour on the quality of rice papad. The Ecoscan, 9(1\&2): 305-310.

Khuyen, T.H.D., Singh, Z., and Swinny, E.E. 2008. Edible coatings influence fruit ripening, quality, and aroma biosynthesis in mango fruit. J. Agric. Food Chem., 56: 1361-1370.

Koley, T.K., Asrey, R., Pal, R.K., and Samuel, D.V.K. 2009. Shelf-life extension in pointed gourd (Trichosanthes dioica Roxb.) by postharvest application of sodium hypochlorite, potassium metabisulphite and carnauba wax. J. Food Sci. Technol., 46(6): 581-584.

Li, H., and Yu, T. 2000. Effect of chitosan on incidence of brown rot, quality, and physiological attributes of postharvest peach fruit. J. Sci. Food Agric., 81: 269274.

Min, S., and Krochta, J.M. 2005. Antimicrobial films and coatings for fresh fruit and vegetables. In: Jongen, $\mathrm{W} .(\mathrm{Ed})$. Improving the safety of fresh fruit and vegetables, New York: CRC Press. pp455-492.

No, H.K., Meyers, S.P., and Prinyawiwatkul, W. 2007. Applications of chitosan for improvement of quality and shelf life of foods: A review. J. Food Sci., 72(5): $87-100$.

Olivas, G.I., and Barbosa-Canovas, G.V. 2005. Edible coatings for fresh-cut fruits. Crit. Rev. Food Sci. Nutr., 45: 657-670.

Parish, E.J., Terrence, L.B., and Shengrong, Li. 2002. The chemistry of waxes and sterols. In: Casimir, C.A., David, B. Min. Food lipids: chemistry, nutrition, and biochemistry $\left(2^{\text {nd }} E d.\right)$. New York: 
M. Dekker. pp-103.

Puttalingamma, V. 2014. Edible coatings of carnauba wax- a novel method for preservation and extending longevity of fruits and vegetables- A review. Int. J. Food Saf., 16: 1-5.

Sadasivam, S., and Manickam, A. 1996.Biochemical Methods ( $\left.2^{\text {nd }} E d n.\right)$ New Age International Publisher, New Delhi, pp. 187-188.

Shahid, M.N., and Abbasi, N.A. 2011. Effect of bee wax coatings on physiological changes in fruits of sweet orange cv. 'Blood Red'. Sarhad J. Agric., 27: 385394.

Singh, D., and Singh, B. 2002. Bio efficacy of Penicillium italicum on the incidence and growth on Kinnow fruits in combination with oil and wax emulsions. Ann. Plant Prot. Sci., 10: 272-276.
Torres, S.M., Garcia, M.V., Juarez, J.V., Alenzuela, J.V., and Corrales, J.C. 2009. Effect of wax application on the quality, lycopene content and chilling injury of tomato fruit. J. Food Qual., 32:735-746.

Wu, Y., Weller, C.L., Hamouz, F., Cuppet, S., and Schnepf, M. 2002. Development and application of multicomponent edible coatings and films: A review. Adv. Food Nutr. Res., 44: 34-39.

Xu, Y.X., Kim, K.M., Hanna, M.A., and Nag, D. 2005. Chitosan-starch composite film: preparation and characterization. Ind. Crops Prod., 21: 185-192.

Yamauchi, N. 2008. Inhibitory effect of sucrose laurate ester on degreening in Citrus nagato-yuzukichi fruit during storage. Postharvest Biol. Technol., 47: 333-337.

\section{How to cite this article:}

Donal Bhattacharjee and Rabi Shankar Dhua. 2017. Impact of Edible Coatings on the Postharvest Behaviour of Bitter Gourd (Momordica charantia L.) Fruits. Int.J.Curr.Microbiol.App.Sci. 6(3): 336-347. doi: https://doi.org/10.20546/ijcmas.2017.603.038 